\title{
EFEKTIFITAS BIO-KOMPOS DAN BIO-POC TERHADAP SERANGAN HAMA PENGGEREK BATANG (Ostrinia furnacalis) PADA JAGUNG MANIS
}

\author{
Yulensri $^{1}$, Misfit Putrina ${ }^{2}$, Kresna Murti ${ }^{3}$ \\ ${ }^{1}$ Program Studi Budidaya Tanaman pangan,Jurusan Budidaya Tanaman Pangan,Politeknik Pertanian \\ Negeri Payakumbuh,Sumatera Barat \\ ${ }^{2,3}$ Program Studi Budidaya Tanaman Perkebunan, Politeknik Pertanian Negeri Payakumbuh,Sumatera \\ Barat \\ email: yulensri87@gmail.com
}

\section{Diserahkan: 3 September $2020 \quad$ Diterima: 7 Desember 2020}

\begin{abstract}
The stem borer (Ostrinia furnacalis Guenee) is one of the main pests of corn. The yield loss due to this pest attack reaches 20-80\%. These pests are generally controlled chemically, causing various negative effects from the results of control, therefore environmentally friendly control techniques are needed, such as the use of bio-compost and bio-LOF. Bio-compost is compost combined with a consortium of bacteria Serratia marcecens, Bacillus thuringiensis and Pseudomonas fluorescens. Bio-LOF is a liquid organic fertilizer that is processed using cow feces, cow urine, Glicerida leaves and coconut husk. The research objective is to determine the effectiveness of bio-compost with several concentrations of bio-LOF to control stem borer pests in sweet corn. The research was conducted at experimental land of Payakumbuh Agricultural Polytechnic from January to June 2020. This study used a factorial completely randomized design (4x3) with 3 replications. Factor K, namely K1; Tithonia bio-compost, K2; Hay bio-compost. K3; Manure bio-compost. K4: without bio-compost. Factor D are: D1; Bio-LOF concentration 30\%, D2; BioLOF 20\%. D3: without Bio-LOF. The data obtained were analyzed for variance using a statistical program of 8.0, then continued with the dancun test $\alpha 5 \%$. The results showed that the three types of bio-compost combined with bio-LOF could reduce the percentage of $O$. furnacalis pest attack on the stems and tips of sweet corn cobs. There were 5 treatment combinations with very effective criteria for coefficient of relatively control (CRC), namely. Tithonia bio-compost, Bio-LOF 30\%, Hay bio-compost, bio-LOF 30\%, chicken feces bio-compost, bio-LOF 30\%, Straw bio-compost, Bio-LOF 20\%, Without bio-compost, BioLOF $30 \%$. The concentration of bio-LOF sprayed on the stems and leaves affects the effectiveness of the control where the $30 \%$ bio-LOF concentration had the very effective criteria of control, while the $20 \%$ concentration had the effective criteria of control.
\end{abstract}

Keywords; Bio-compost, bio-LOF, Ostrinia furnacalis, sweet corn.

\section{PENDAHULUAN}

Jagung manis umumnya dikonsumsi dalam bentuk jagung muda yang direbus atau dibakar. Kebutuhan akan jagung manis semakin meningkat. Data Badan Pusat Statistik (2015) menunjukkan bahwa terjadi peningkatan impor jagung manis sebesar $6.26 \%$ per tahun, dikarenakan jagung manis nasional belum dapat mencukupi permintaan pasar. Produktivitas rata-rata jagung manis Indonesia 8,31 ton/ha (Muhsanati et al. 2006) dengan potensi hasil jagung manis mencapai 14 sampai 18 ton/ha.

Faktor pembatas utama dalam budidaya jagung manis adalah gangguan organisme pengganggu tanaman (OPT), karena jagung manis merupakan salah satu jenis tanaman yang rentan terhadap serangan berbagai jenis hama dan patogen tanaman. Penggerek batang O. furnacalis adalah salah satu hama utama pertanaman jagung. Hama ini awalnya menyerang daun, kemudian menggerek batang 
yang ditandai dengan adanya sisa hasil gerekan pada bagian lubang gerek (Abdullah dan rauf, 2011). Hama ini juga menyerang pangkal tongkol jagung manis. Larva membuat saluran-saluran di dalam batang selagi menggerogoti jaringan untuk makanannya, sehingga ia disebut juga penggerek batang jagung atau Asian corn borer. Penyebutan "asia" digunakan untuk membedakannya dari penggerek batang jagung di kawasan beriklim sedang, European corn borer(O. nubilalis) (Subiadi dan Sipi, 2018).

Pengendalian $O$. furnacalis saat ini bergantung pada pestisida, sehingga menyebabkan efek negatif seperti pencemaran lingkungan, ancaman terhadap kesehatan manusia, resistensi hama bahkan terjadinya ledakan hama sekunder. Oleh sebab itu perlu dikembangkan teknik pengendalian lain yang dapat meminimalkan bahkan memperbaiki efek negatif pestisida kimia seperti penggunaan bioteknologi yaitu Bio-kompos dan Bio-POC yang dapat berperan sebagai biopestisida.

Bio-kompos adalah kompos yang digabung dengan konsorsium bakteri Pseudomonas fuorescens, Serratia marcecens dan Bacillus thuringiensis dengan total coloni bakteri konsorsium 5,6 x10 $\mathrm{CFU}$ /gram sampel. Penelitian ini menggunakan 3 jenis Biokompos yaitu Bio-kompos tithonia, Biokompos jerami dan Bio-kompos fases ayam, penambahan konsorsium bakteri dalam pupuk kompos dapat meningkatkan kadar $\mathrm{N}$ total dari $0,013 \%$ menjadi $0,196 \%$, P2O5 menurun dari
0,036 menjadi 0,026\%, meningkatkan kadar $\mathrm{K}_{2} \mathrm{O}$ dari $0,086 \%$ menjadi $0,394 \%$ dengan $\mathrm{pH}$ 8,36. Bio-POC yang digunakan diproses dengan memfermentasikan urin sapi, feses ayam, sapi dan kambing ditambah dengan sabut kelapa dan daun Gliricidia. Kandungan hara dari Bio-POC adalah N; 0,196\%, P2O2: $0,026 \%$, Total k2O; 0,39\% dan konsorsium bakteri $P$. fuorescens, S. marcecens dan $B$. thuringiensis. Dengan populasi 29,3 x10 CFU/gram sampel. (Yulensri dkk,2018).

$P$. fuorescens, S. marcecens dan $B$. thuringiensis adalah bakteri yang banyak dilaporkan sebagai pengendali hama dan penyakit tanaman karena memproduksi enzim khitinase, Protease dan sellulase, efektif untuk mengendalikan penyakit bercak coklat oleh $H$. oryzae dan kembang api oleh E. oryzae secara invitro di laboratorium (Yulensri dkk, 2018)

$P$. fuorescens, $S$. marcecens dan $B$. thuringiensis dapat digunakan dapat dikonsorsiumkan karena tidak terjadi kompetisi apabila ditumbuhkan pada 1 media secara bersama. Beberapa bakteri yang dikonsorsiumkan mempunyai potensi yang lebih bagus daripada isolate tunggal. Menurut asri dan Zulaika (2016) konsorsium merupakan campuran populasi mikroba dalam bentuk komunitas yang mempunyai hubungan kooperatif, komensalis dan mutualistik.

Putrina (2003), melaporkan bahwa dari 43 isolat hasil isolasi dari tanah pada berbagai ekosistem di Sumatera Barat, 17 isolat menunjukkan patogenisitas $>50 \%$ terhadap hama Spodoptera litura dan 3 isolat (SB II 1 
dan 5 dan TSTM 1) menunjukkan efektifitas yang tinggi. Dari uji lapangan isolat SB II 1 memberikan hasil mortalitas 54,35\% dengan $\mathrm{LT}_{50}$ 171,55 jam terhadap hama $S$. litura pada tanaman kedelai.

B. thuringiensis pada media air rendaman kedelai dapat menekan serangan hama Lepidoptera pemakan daun tembakau sebesar 18,2\% dibandingkan dengan kontrol ( Putrina dan Fardedi, 2007) .

Perlakuan benih dengan ryzobakteria P.fluorescen, B. thuringiensis, S. marcecens dapat meningkatkan viabilitas benih, pertumbuhan dan produksi tanaman padi metode SRI, mengurangi tingkat serangan penyakit bercak coklat pada daun padi sampai dengan $90 \%$ dan pada gabah $35,7 \%$ sampai dengan $37,5 \%$, meningkatkan mutu fisiologis benih (viabilitas benih dan vigor), meningkatkan mutu patologis benih jika dibanding dengan control (Yulensri dkk. ,2015). Formulasi B. thuringiensis SB1 dan $S$. marcecens SLK dan P. fluorescens PYK pada media EKG mempunyai jumlah koloni yang lebih banyak (5 - 22,6 $10^{9} \mathrm{CFU} / \mathrm{ml}$ sampel) dari pada media AKG (2- $4 \times 10^{9} / \mathrm{ml}$ sampel)) dan media padat $\left(0,7-2,4 \times 10^{9} \mathrm{CFU} / \mathrm{gr}\right.$ sampel) serta berbeda nyata menurut Uji duncan (Yulensri, dkk,2016).

Tujuan penelitian adalah untuk mengetahui efektifitas Bio-kompos dengan Bio-POC untuk untuk mengendalikan hama $O$. furnacalis pada tanaman jagung manis

METODE PENELI TIAN
Penelitian di lakukan di kebun percobaan Politeknik Pertanian Negeri Payakumbuh Mulai Januari sampai Juni 2020. Penelitian menggunkan Rancangan acak lengkap berpola faktorial $(4 \times 3)$ dengan 3 ulangan. Factor $\mathrm{K}$ yaitu K1; Bio-kompos tithonia, K2. Biokompos jerami. K3; Bio-kompos kotoran ternak. K4: tanpa Bio-kompos. Factor D adalah konsentrasi Bio-POC yaitu : D1:konsentrasi BIO-POC 30\%, D2. BIO-POC 20 \%. D3 : tanpa BIO-POC. Terdapat 12 kombinasi perlakuan dan 3 ulangan. Biokompos diberikan dengan dosis 9 ton/Ha, sedangkan BIO-POC diberikan sebanyak 3 kali yaitu pada saat tanam dengan menyiramkan pada lobang tanaman dan diulang pada penyiangan I dan penyiangan kedua dengan cara penyemprotan pada seluruh bagian tanaman yakni daun, batang dan pangkal batang lalu ditimbun, pekerjaan ini sejalan dengan pembumbunan tanaman jagung. Variabel yang diamati adalah persentase serangan $O$. furnacalis pada batang dan pada ujung tongkol serta Koefisien Relatif pengendalian (KRP).

Persentase serangan pada batang dan tongkol diamati dengan menggunakan rumus :

$$
\text { Persentase serangan }(\mathrm{P})=\frac{n}{N} \times 100 \%
$$

Keterangan:

$\mathrm{n}=$ Jumlah sampel tanaman yang terserang $O$. furnacalis

$\mathrm{N}=$ Jumlah sampel tanaman yang diamati

Keefektifan Relatif Pengendalian (KRP) 
Penghitungan Keefektifan Relatif pengendalian hama $O$. furnacalis dilakukan dengan menggunakan rumus :

$$
\text { KRP = --------------- x } 100 \% \text {, dimana }
$$

$\mathrm{KRP}=$ Keefektifan relatif pengendalian

$\mathrm{PIK} 0=$ Persentase serangan pada petakan Kontrol

PIP $=\underset{\text { Persentase serangan pada petak }}{\text { perlakuan }}$

Kriteria keefektifan pengendalian tiap perlakuan ditentukan sebagaimana yang tertera pada Tabel 1 :

Tabel1. Kriteria keefektifan relatif pengendalian hama $O$. furnacalis

\begin{tabular}{ll}
\hline Nilai Keefektifan & $\begin{array}{l}\text { Kategori } \\
\text { Relatif Pengendalian } \\
\text { keefektifan }\end{array}$ \\
\hline KRP $\geq 80 \%$ & Sangat efektif \\
$60 \% \leq \mathrm{KRP}<80 \%$ & Efektif \\
$40 \% \leq \mathrm{KRP}<60 \%$ & Agak efektif \\
$20 \% \leq \mathrm{KRP}<40 \%$ & Kurang efektif \\
\hline KRP <20\% & Tidak efektif \\
\hline \multicolumn{2}{c}{ Data yang diperoleh dianalisis varian } \\
menggunakan program statistik $8.0 \quad$ dan \\
dilanjutkan dengan uji Duncan
\end{tabular}

\section{HASIL DAN PEMBAHASAN}

Serangan hama $O$. furnacalis baru terlihat dilapang setelah tanaman memesuki fase generatif yaitu pada saat tongkol sudah berisi dengan tingkat serangan 1-4\% ( Tabel 2)

Serangan penggerek batang tertinggi terdapat pada perlakuan tanpa pemberian Biokompos dan Bio-POC dan yang terendah terdapat pada perlakuan Bio-kompos jerami yang dikombinasi dengan Bio-POC konsentrasi $30 \%$.
Tabel 2. Persentase serangan $O$. furnacalis pada batang jagung manis umur 60 hari setelah tanam (hst) $(\%)$

\begin{tabular}{|c|c|c|c|c|}
\hline \multirow{2}{*}{$\begin{array}{l}\text { perlakuan } \\
\text { jenis Bio- } \\
\text { kompos }\end{array}$} & \multicolumn{3}{|c|}{ Konsentrasi BIO-POC } & \multirow{2}{*}{$\begin{array}{l}\text { Pengaruh } \\
\text { utama Bio } \\
\text { kom pos }\end{array}$} \\
\hline & $\begin{array}{l}\text { D1 } \\
30 \%\end{array}$ & $\begin{array}{l}\mathrm{D} 2 \\
20 \%\end{array}$ & $\begin{array}{l}\text { D3 } \\
0 \%\end{array}$ & \\
\hline $\begin{array}{l}\text { K1(biokom } \\
\text { pos tithonia) }\end{array}$ & $1,0 \mathrm{ab}$ & $1,3 \mathrm{ab}$ & $2,3 \mathrm{ab}$ & $1,5 \mathrm{a}$ \\
\hline $\begin{array}{l}\text { K2(biokom } \\
\text { pos jerami) }\end{array}$ & $0,0 \mathrm{~b}$ & $2,0 \mathrm{ab}$ & $3,6 \mathrm{ab}$ & $1,8 \mathrm{a}$ \\
\hline $\begin{array}{l}\text { K3(biokom } \\
\text { pos feses } \\
\text { ayam) }\end{array}$ & $2,0 \mathrm{ab}$ & $2,7 \mathrm{ab}$ & $3,0 \mathrm{ab}$ & 2,4 a \\
\hline $\begin{array}{l}\text { K4(tanpa } \\
\text { Bio-kompos) }\end{array}$ & $0,6 \mathrm{ab}$ & $2,7 \mathrm{ab}$ & $4.0 \mathrm{a}$ & $2,5 \mathrm{a}$ \\
\hline $\begin{array}{l}\text { Pengaruh } \\
\text { utama } \\
\text { Konsentrasi } \\
\text { Bio-POC }\end{array}$ & $1,4 \mathrm{a}$ & $2,3 \mathrm{a}$ & $2,5 \mathrm{a}$ & \\
\hline
\end{tabular}

Kedua perlakuan ini memperlihatkan perbedaan yang nyata menurut uji duncan dengan $\alpha \quad 5 \%$. Sedangkan kombinasi perlakuan yang lain berbeda tidak nyata menurut uji duncan. Serangan penggerek batang baru terlihat setelah tongkol mulai berisi, hama ini umumnya menggerek batang pada buku di dekat tongkol (Gambar 1)

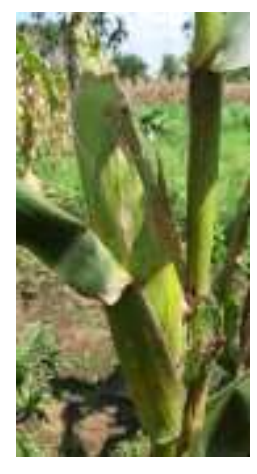

$1 \mathrm{a}$

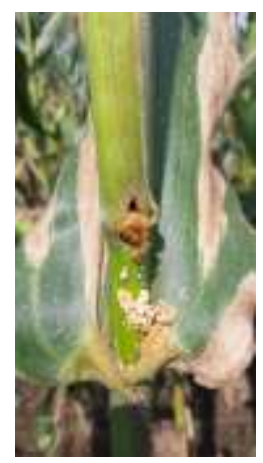

$1 \mathrm{~b}$

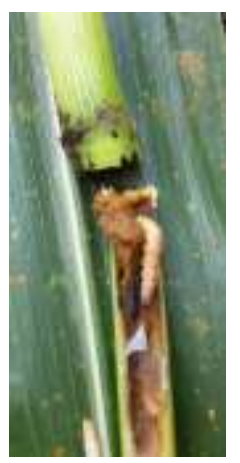

$1 \mathrm{c}$
Gambar 1. Gejala serangan $O$. furnacalis pada batang jagung manis

Gambar 1 memperlihatkan bahwa serangan O. furnacalis pada batang tidak berpengaruh pada tongkol karena gejela serangan baru terlihat setelah tongkol berisi (1a,1b). 
Akan tetapi hama ini sudah membentuk pupa di dalam batang (gambar 1c), dan akan selalu ada di lapangan. Pada saat panen hama ini juga terdapat pada ujung tongkol jagung manis dengan tingkat serangan yang disajikan pada Tabel 3 .

Tabel 3. Persentase serangan $O$. furnacalis pada ujung tongkol jagung manis saat panen $(\%)$

\begin{tabular}{|c|c|c|c|c|}
\hline \multirow{2}{*}{$\begin{array}{l}\text { perlakuan } \\
\text { jenis Bio- } \\
\text { kompos }\end{array}$} & \multicolumn{3}{|c|}{ Konsentrasi BIO-POC } & \multirow{2}{*}{$\begin{array}{l}\text { Pengaruh } \\
\text { utama Bio } \\
\text { kom pos }\end{array}$} \\
\hline & $\begin{array}{l}\text { D1 } \\
30 \%\end{array}$ & $\begin{array}{l}\text { D2 } \\
20 \%\end{array}$ & $\begin{array}{l}\text { D3 } \\
0 \%\end{array}$ & \\
\hline $\begin{array}{l}\text { K1(biokom } \\
\text { pos tithonia) }\end{array}$ & $3,3 \mathrm{~b}$ & $2,0 \mathrm{ab}$ & $8,0 \mathrm{ab}$ & $4,0 \mathrm{a}$ \\
\hline $\begin{array}{l}\text { K2(biokom } \\
\text { pos jerami) }\end{array}$ & $3,0 \mathrm{~b}$ & $4,0 \mathrm{~b}$ & $5,3 \mathrm{ab}$ & $4,1 \mathrm{a}$ \\
\hline $\begin{array}{l}\text { K3(biokom } \\
\text { pos feses } \\
\text { ayam) }\end{array}$ & $4,0 \mathrm{~b}$ & $5,0 \mathrm{~b}$ & $3,0 \mathrm{~b}$ & $4,4 \mathrm{a}$ \\
\hline $\begin{array}{l}\text { K4(tanpa } \\
\text { Bio-kompos) }\end{array}$ & $1,0 \mathrm{~b}$ & $5,0 \mathrm{~b}$ & $18,3 \mathrm{a}$ & $8,1 \mathrm{a}$ \\
\hline $\begin{array}{l}\text { Pengaruh } \\
\text { utama } \\
\text { Konsentrasi } \\
\text { Bio-POC }\end{array}$ & $2,0 \mathrm{a}$ & $4,0 \mathrm{~b}$ & $8,6 \mathrm{~b}$ & \\
\hline
\end{tabular}

Huruf yang berbeda menunjukkan pengaruh yang nyata $(p<0,05)$

Persentase serangan pengggerek batang pada ujung tongkol lebih tinggi jika dibandingkan dengan serangan pada batang (Tabel 3). Pada perlakuan tanpa Bio-kompos dan Bio-POC rata-rata persentase serangan $13,8 \%$, sedangkan pada batang hanya $4 \%$. Persentase serangan pada ujung tongkol terendah terdapat pada perlakuan aplikasi BioPOC 30\% tanpa Bio-kompos. Disini terlihat bahwa konsentrasi penyenprotan Bio-POC berpengaruh pada persentase serangan $O$. furnacalis pada ujung tongkol dimana BioPOC yang diaplikasikan dengan konsentrasi $30 \%$ mempunyai tingkat serangan yang paling rendah dan berbeda nyata dengan aplikasi Bio-
POC $20 \%$ dan tanpa Bio-POC berdasarkan uji duncan

Koefisien relatif pengendalian (KRP) masing-masing kombinasi perlakuan Biokompos dan Bio-POC dapat dilihat pada Tabel 4.

Tabel 4. Nilai Koefisien relatif pengendalian O. furnacalis dengan kombinasi Biokompos dan Bio-POC pada ujung tongkol jagung manis.

\begin{tabular}{|c|c|c|}
\hline Kombinasi perlakuan & $\begin{array}{l}\text { Nilai } \\
\text { Koefisien } \\
\text { relatif } \\
\text { pengendalian } \\
(\mathrm{KRP})(\%) \\
\end{array}$ & $\begin{array}{l}\text { Kriteria } \\
\text { keefektifan } \\
\text { hasil } \\
\text { pengendalian }\end{array}$ \\
\hline $\begin{array}{l}\text { Tanpa Bio-kompos dan } \\
\text { BIO-POC }\end{array}$ & 0,0 & Tidak efektif \\
\hline $\begin{array}{l}\text { Bio-kompos Tithonia, } \\
\text { tanpa Bio-POC }\end{array}$ & 56,3 & Agak efektif \\
\hline $\begin{array}{l}\text { Bio-kompos jerami, } \\
\text { tanpa Bio-POC }\end{array}$ & 71,0 & Efektif \\
\hline $\begin{array}{l}\text { Bio-kompos fese ayam, } \\
20 \% \text { Bio-kompos }\end{array}$ & 72,7 & Efektif \\
\hline $\begin{array}{l}\text { Tanpa Bio-kompos,Bio- } \\
\text { POC } 20 \%\end{array}$ & 72,7 & Efektif \\
\hline $\begin{array}{l}\text { Bio-kompos feses } \\
\text { ayam, tanpa Bio-POC }\end{array}$ & 78,2 & Efektif \\
\hline $\begin{array}{l}\text { Bio-kompos jerami, } \\
\text { Bio-POC } 20 \%\end{array}$ & 78,2 & Efektif \\
\hline $\begin{array}{l}\text { Bio-kompos Tithonia, } \\
\text { Bio-POC } 30 \%\end{array}$ & 83,4 & $\begin{array}{l}\text { Sangat } \\
\text { efektif }\end{array}$ \\
\hline $\begin{array}{l}\text { Bio-kompos jerami, } \\
\text { Bio-POC } 30 \%\end{array}$ & 83,6 & $\begin{array}{l}\text { Sangat } \\
\text { efektif }\end{array}$ \\
\hline $\begin{array}{l}\text { Bio-kompos feses } \\
\text { ayam, Bio-POC } 30 \%\end{array}$ & 83,6 & $\begin{array}{l}\text { Sangat } \\
\text { efektif }\end{array}$ \\
\hline $\begin{array}{l}\text { Bio-kompos jerami, } \\
\text { Bio-POC } 20 \%\end{array}$ & 89,1 & $\begin{array}{l}\text { Sangat } \\
\text { efektif }\end{array}$ \\
\hline $\begin{array}{l}\text { Tanpa Bio-kompos, } \\
\text { Bio-POC } 30 \%\end{array}$ & 94,5 & $\begin{array}{l}\text { Sangat } \\
\text { efektif }\end{array}$ \\
\hline
\end{tabular}

Bio-kompos yang dikombinasi dengan BioPOC mempunyai kriteria hasil penggendalian sangat efektif untuk mengendalikan hama O.furnacalis pada tongkol jagung manis. Kombinasi Bio-kompos tithonia, Bio-kompos jerami dan Bio-kompos feses ayam dengan konsentrsi Bio-POC $30 \%$ memberikan kriteria hasil pengendalian yang sangat fektif, jika kitiga jenis Bio-kompos tersebut 
dikombinasikan dengan Bio-POC dengan konsentrsi $20 \%$ dan tanpa Bio-POC mempunyai kriteria hasil pengendalian yang efektif kecuali kompos Tithonia jika tidak dikombinasi dengan Bio-POC mempunyai kriteria hasil pengendalian yang agak efektif.

\section{PEMBAHASAN}

Hasil pengamatan persentase serangan penggerek batang pada batang jagung manis (Tabel2) dan pada ujung tongkol jagung manis (Tabel 3) memperlihatkan bahwa ketiga jenis Bio-kompos yang diuji yang dikombinasi dengan Bio-POC dapat menekan persentase serangan hama $O$. furnacalis . Konsentrasi Bio-POC mempengaruhi kriteria keefektifan hasil pengendalian dimana konsentrasi BioPOC sebanyak $30 \%$ mempunyai nilai KRP dengan kriteria hasil pengendalian sangat efektif, sedangkan dengan konsentrasi BioPOC 20\% mempunyai nilai KRP dengan kriteria yang efektif. Hal ini disebabkan baik pada Bio-kompos maupun Bio-POC mengandung konsorsium bakteri S. marcecens, $P$. fluorescens dan $B$. thuringiensis dengan jumlah koloni 5,6 x10 $\mathrm{CFU}$ /gram sampel pada Bio-kompos dan 29,3 x10 $\mathrm{CFU} / \mathrm{ml}$ sampel pada Bio-POC. Ketiga bakteri yang dikonsorsiumkan ini sudah banyak dilaporkan kemampuannya sebagai agens hayati pengendali hama dan penyakit tanaman. $S$. marcecens, B.thuringiensis, P. fluorescen dapat berperan sebagai plant growth promoting regulator (PGPR) karena merupakan bakteri pelarut fosfat dan memproduksi IAA, dapat dijadikan sebagai agens pengendali penyakit karena memproduksi enzim khitinase, Protease dan sellulase, dapat digunakan secara bersama (dikonsorsiumkan) karena tidak terjadi kompetisi apabila ditumbuhkan pada 1 media, efektif untuk mengendalikan penyakit bercak coklat oleh $H$. oryzae dan kembang api oleh E. oryzae secara invitro di laboratorium. dan di lapang (Yulenseri dkk, 2013; Yulensri dkk., 2017).

Serratia marcescens merupakan bakteri yang patogen terhadap serangga karena dapat menghasilkan beberapa enzim hidrolitik seperti protease, kitinase, nuclease, dan lipase yang bersifat toksin (Flyg et al 1983). Bakteri ini juga dapat menghasilkan serrawetin, senyawa surfaktan yang membantu dalam proses kolonisasi (Hejazi \&Falkiner 1997). Bakteri merah juga dilaporkan bersifat patogenik terhadap Spodoptera exigua, Plutella xylotella, Crocidolomia binotallis, kutu daun mangga (Rastrococcus sp.), dan belalang berkembar (Wibowo et al., 2002). Hal ini menunjukkan bahwa bakteri merah mempunyai sebaran inang yang cukup luas pada serangga sasaran.

Bacillus thuringiensis adalah bakteri yang menghasilkan kristal protein yang bersifat membunuh serangga (insektisidal) sewaktu mengalami proses sporulasinya (Hofte dan Whiteley, 1989). Kristal protein yang bersifat insektisidal ini sering disebut dengan $\delta$ endotoksin. Kristal ini sebenarnya hanya merupakan protoksin yang jika larut dalam 
usus serangga akan berubah menjadi polipeptida yang lebih pendek (27-149 kd) serta mempunyai sifat insektisidal.

Putrina (2003), melaporkan bahwa dari 43 isolat hasil isolasi dari tanah pada berbagai ekosistem di Sumatera Barat, 17 isolat menunjukkan patogenisitas $>50 \%$ terhadap hama Spodoptera litura dan 3 isolat (SB II 1 dan 5 dan TSTM 1) menunjukkan efektifitas yang tinggi. Dari uji lapangan isolat SB II 1 memberikan hasil mortalitas 54,35\% dengan $\mathrm{LT}_{50}$ 171,55 jam terhadap hama $S$. litura pada tanaman kedelai.

Putrina dan Fardedi (2007), dari uji lapangan, biakan B. thuringiensis pada media air rendaman kedelai dapat menekan serangan hama Lepidoptera pemakan daun tembakau sebesar 18,2\% dibandingkan dengan kontrol.

Hasil pengamatan juga mempelihatkan bahwa konsentrasi Bio-POC mempengaruhi nilai KRP hasil pengendalian dimana konsentrasi tertinggi (30\%) memberikan nilai KRP dengan kriteria sangat efektif, sedangkan konsentrasi $20 \%$ dengan kriteria efektif dan tanpa Bio-POC tidak efektif. Hal ini disebabkan sifat larva instar lanjut hama $O$. furnacalis yang berada di dalam batang sampai membentuk imago. Sehingga penyemprotan Bio-POC pada batang menyebabkan bakteri $S$. marcecens, B.thuringiensis, $P$. fluorescen dapat membunuh $O$. furnacalis dengan masuk melalaui lubang gerekan semakin tinggi konsentrasi Bio-POC yang diberikan maka semakin banyak sel bakteri yang dapat memasuki lubang gerekan hama. Larva $O$. furnacalis instar lanjut umumnya menggerek ke dalam batang dan membentuk pupa di dalam batang jagung. Sedangkan serangan pada ujung tongkol umumnya pada jagung manis yang tongkolnya dipanen muda sehingga berpengaruh nyata pada kelayakan jual (Abdullah dan Rauf, 2011)

\section{KESIMPULAN}

Dari hasil penelitian dapat disimpulkan bahwa :

Ketiga jenis Bio-kompos yang dikombinasi dengan Bio-POC dapat menekan persentase serangan hama $O$. furnacalis pada batang dan ujung tongkol jagung manis dengan kriteria hasil pengendalian sangat efektif untuk lima (5) kombinasi perlakuan yaitu: Bio-kompos Tithonia, Bio-POC 30\%, Bio-kompos jerami, Bio-POC 30\%, Bio-kompos feses ayam, BioPOC 30\%, Bio-kompos jerami, Bio-POC 20 $\%$, Tanpa Bio-kompos, Bio-POC $30 \%$.

Konsentrasi Bio-POC yang disemprotkan pada batang dan daun mempengaruhi efektifitas pengendalian dimana konsentrasi Bio-POC $30 \%$ mempunyai kriteria hasil pengendalian sangat efektif sedangkan konsentrasi $20 \%$ mempunyai kriteria hasil pengendalian yang efektif.

\section{SARAN}

Untuk mengendalikan hama penggerek batang yang menyerang tanaman jagung mulai fase vegetatif sampai saat panen (tongkol), sebaiknya Bio-POC diberikan secara rutin setiap 2 minggu sekali mulai saat tanam untuk 
mencegah serangan hama O.furnacalis di lapang.

\section{UCAPAN TERIMA KASIH}

Penulis mengucapkan terima kasih kepada DRPM Ristekdikti yang telah memberi dukungan financial terhadap penelitian ini dan dan Direktur Politeknik Pertanian Negeri Payakumbuh yang telah memfasilitasi pelaksanaan penelitian.

\section{DAFTAR PUSTAKA}

Abdullah,T. dan Rauf. A. 2011. Karakteristik Populasi dan Serangan Penggerek Batang Jagung Asia, Ostrinia furnacalis (Lepidoptera: Pyralidae), dan Hubungannya dengan Kehilangan Hasil. Jurnal Fitomedika Vol. 7. No 3, April 2011. pp.175-181.

Asri,A.,C dan E., Zulaika. 2016. Sinergisme Antar Isolat Azotobacter Yang Dikonsorsiumkan. Jurnal sains dan seni ITS Vol. 5, No.2, (2016) 2337-3520

Bato SM, Everett TR, Malijan OO. (1983). Integrated Pest Management for Asian Corn.

[BPS] Badan Pusat Statistik. 2015. Statistik ekspor impor komoditas pertanian 2001 2014. \{www.bps.go.id\}[14 Agustus 2020].

Flyg Casper dan Xanthopoulos G Kleanthis. 1983. Insect phatogenic properties of $\mathrm{S}$. marcescens passive and active resistance to insect immunity studied with proteasedeficient and phage - resistance mutants. Journal of General microbiology 129 :453464.

Hejazi, A. and Falkiner, F.R. (1997) Serratia marcescens. Journal of Medical Microbiology,46,903-912. http://dx.doi.org/10.1099/00222615-46-11$\underline{903}$

Hofte, H. and H.R. Whiteley. 1989. Insecticidal crystal proteins of Bacillus thuringiensis. Microbiol. Rev. 53: 42-255

Muhsanati, Syarif, Rahayu. 2006. Pengaruh beberapa takaran kompos Tithonia terhadap pertumbuhan dan hasil tanaman jagung manis (Zea mays saccharata Sturt.). J.Jerami 1 (2) : 87-91.

Putrina, M. 2003. Isolasi Bacillus thuringiensis Berliner dari tanah pada beberapa ekosistem dan patogenisitasnya terhadap Spodoptera litura Fabricius. Tesis. Tidak diterbitkan. Program Pascasarjana Universitas Andalas. Padang. 81 hal.

Putrina, M. dan Fardedi. 2007. Pemanfaatan air kelapa dan air rendaman kedelai sebagai media perbanyakan bakteri Bacillus thuringiensis Berliner. Jurn. Ilmu Pert. Indon. 9(1):64-70.

Rubatzky, V.E. and Yamaguchi M. 1997. "World Vegetables: Principles, Production, and Nutritive Values". Thomson Publishing Inc. 292 p. [8] Kasno, A., 2005. "Profil dan Perkembangan Teknik Produksi Kacang Tanah Di Indonesia". Makalah pada Seminar Rutin Puslitbang Tanaman Pangan,

Wibowo, B.S., L. Retnowati, A. Sutaryat, C. Irwan, dan Y. Kurniadi. 2002. Uji Lapang Bakteri Merah terhadap Wereng Batang Coklat (Di Daerah Endemis). Laporan Kajian. Balai Penelitian Organisme Pengganggu Tanaman, Jatisari, Tahun 2002. $21 \mathrm{hlm}$.

Yulensri, Agustamar, dan M. Putrina. 2013. Potential of Serratia marcecens SLK, Bacillus thuringiensis SB1 and Pseudomonas fluorescens PYK indigenusas udbatta desease control and its influence on the growth of rice seedlings. Proceeding internacional conference of green city desing; Bukittinggi.

Yulensri, Agustamar, 2016. Penerapan pupuk organik padat dan cair pada budidaya padi organik metode SRI di Kanagarian Taram. Kab. Limapuluh kota. Prosiding seminar nasional membangun sektor perkebunan masa depan untuk meningkatkan produktivitas pertanian ISBN978=979=98699-7.

Yulensri, Wahono,S. dan Darnetty. 2017. Penerapan pupuk bioorganik padat dan cair (Bio-POC) pada budidaya pare organik. Prosiding seminar nasional perubahan iklim terhadap biodiversitas pertanian indonesia. ISBN978=979=9896 3-0 
Yulensri, Putrina dan Murti EFEKTIFITAS BIO-KOMPOS DAN BIO-POC...

Yulensri, Putrina, M., Arneti. 2018. Investigation Potency Serratia marcecens Indigenoes in Controlling Udbatta Disease that is Caused by Ephelis oryzae at Invitro Test. https://eudl.eu/pdf/10.4108/eai.24-1$\underline{2018.2292407}$ 